\title{
Primary Squamous Cell Carcinoma of the Breast: A Case Report
}

\author{
Memenin Primer Yassı Hücreli Karsinomu: Olgu Sunumu
}

Hande Köksal', Meryem Illkay Eren Karanis ${ }^{2}$, Ersin Turan¹, Süleyman Said Kökçam , Osman Doğru

${ }^{1}$ Sağlık Bilimleri University, Konya Education and Research Hospital, Department of General Surgery, Konya, Turkey

${ }^{2}$ Sağlık Bilimleri University, Konya Education and Research Hospital, Department of Pathology, Konya, Turkey

\section{ABSTRACT}

The squamous cell carcinoma of the breast is an uncommon neoplasm. Herein we report a patient with primary squamous cell carcinoma of the breast in order to discuss the general approaches to this disease and treatment modalities.

Key Words: Breast, squamous cell carcinoma, treatment

\section{ÖZET}

Memenin yassı hücreli karsinomu nadir görülen bir tümördür. Burada memede primer yassı hücreli karsinom tanısı alan bir hasta, tanı ve tedavi yaklaşımlarının tartışılması amacıyla sunulmuştur.

Anahtar Sözcükler: Meme, yassı hücreli karsinom, tedavi

Geliş Tarihi: 03.12.2016

Kabul Tarihi: 16.01 .2017

\section{INTRODUCTION}

The squamous cell carcinoma of the breast is an uncommon neoplasm, which comprises $0.04-0.1 \%$ of all breast carcinomas (1). The data about its epidemiology, clinical presentation, radiologic images, biological behaivour and outcomes are limited and based on single reports. In general, they are rapidly progressing tumors with resistance to the treatment and poor prognosis. Herein we report a patient with primary squamous cell carcinoma of the breast in order to discuss the general aproaches to this disease and treatment modalities.

\section{CASE REPORT}

An 82 year-old patient was admitted to our breast centre with a complaint of a growing mass on left breast for two years. Physical examination revealed a gross mass, $9 \times 8 \mathrm{~cm}$ in diameter, located on the lateral border of left breast. The lesion was painless, well circumscribed and mobile. Breast ultrasound and mammography revealed a well-defined mass which is $10 \mathrm{~cm}$ in diameter with reactive axillary lymph nodes (Fig.1). 


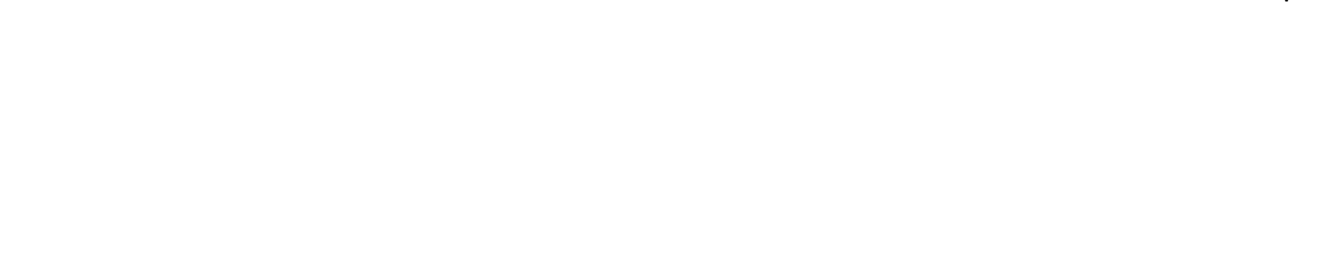

Figure 1a: CC mammogram of the left breast, 1b: MLO mammogram of the breast, at left, a well defined opacity is seen without any microcalcifications.

Fine needle aspiration biopsy of the breast was benign and concordant with complicated cyst and wide local excision was planned. Tumor markers CEA and CA 15-3 were in normal limits. During the operation the frozen section diagnosis of the lesion was reported as "malignant" so left mastectomy with sentinel lymph node sampling was performed. In the cross sectional examination of the mastectomy specimen, a cystic lesion, 9 $\mathrm{cm}$ in diameter, containing red- brownish fluid with irregular inner surface was revealed. There was a hard-surfaced solid tumoral lesion, $3.5 \times 3.5 \times 2 \mathrm{~cm}$ in dimensions, located on posterior wall of this cystic lesion. Microscopical examination of the cyst wall revealed dysplasia areas.
Pleomorphic tumor cells with large, keratinized cytoplasm, large and vesiculated nucleus were forming islands in solid areas histopathologically (Fig.2). After immunhistochemical staining of the specimen, squamous cell carcinoma was diagnosed with CK 5/6 (+) while ER, PR, C-erb B2 were negative. Ki-67 was reported to be $45 \%$. After the pathological diagnosis, whole body physical examinations including oral and anal regions were repeated and no other finding matched with squamous cell carcinoma was detected so the patient was diagnosed as primary breast squamous cell carcinoma. Chemotherapy regimen including zoledronic acid, cyclophosphamide and docetaxel was administered because of multiple bone, lung and mediastinal lymph node metastasis. She was died because of progressive disease after 24 months from the diagnosis.
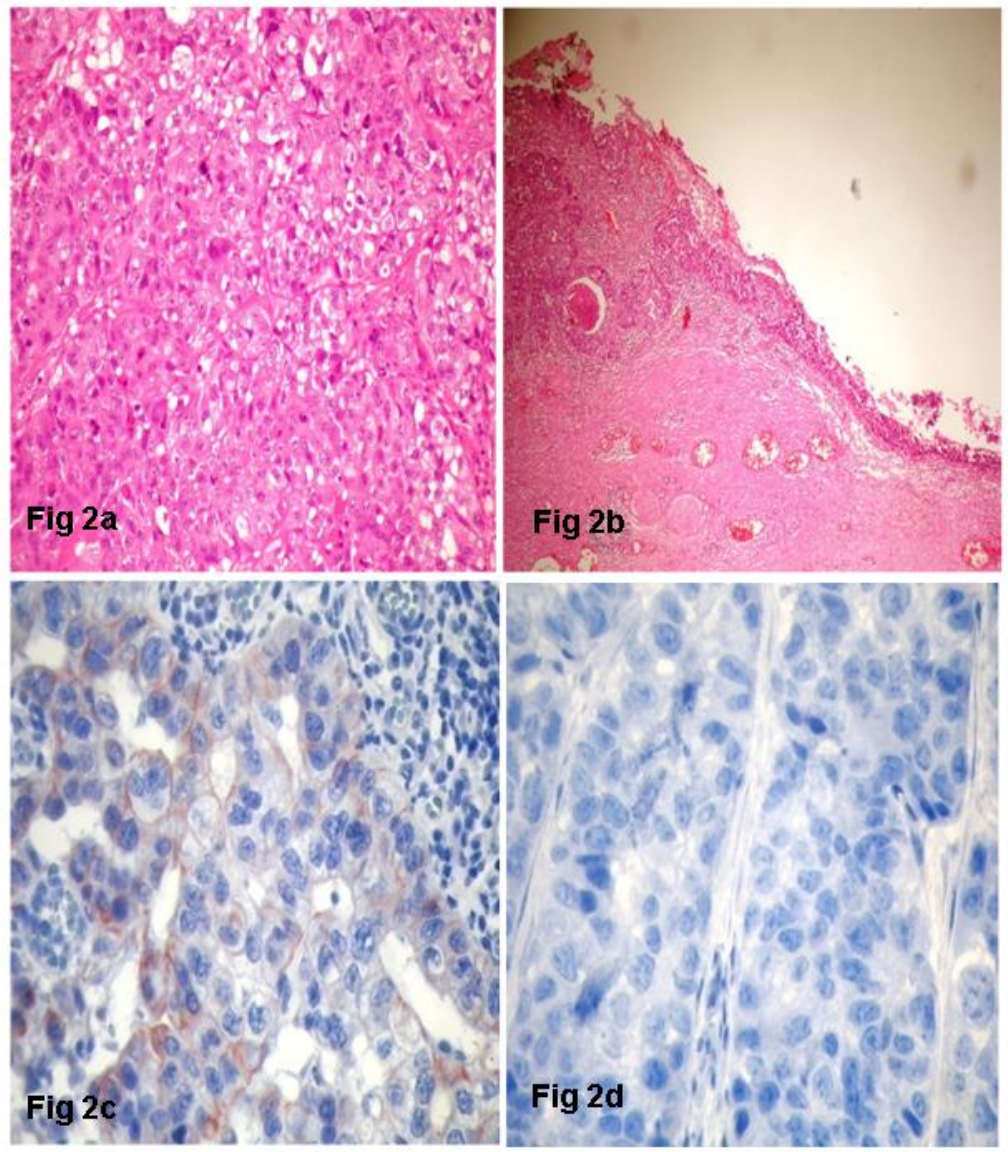

Figure 2a: The microscopic view of solid components of the tumor, HEX200; $\mathbf{2 b}$ : cystic component of the tumor, HEX50; $\mathbf{2 c}$ : CK 5/6 positivity, CK5/6X400; $\mathbf{2 d}$ : PR negative, PRX400 

DISCUSSION

Primary squamous cell carcinoma of the breast is a rarely seen tumor that comprises nearly $0.1 \%$ of all breast carcinomas (1). Macia et al. concluded the criteria needed to diagnose as primary breast squamous cell carcinoma as follows: squamous cell carcinoma should be the only malignancy reported in breast specimen, it shouldn't be the metastasis of another primary tumor located in somewhere else and it should be proved that the tumor is not originating from breast skin.(2).

According to the data by Hennessy et al, it is a rapidly progressive disease with biologically aggressive behavior, often with locoregional and distant metastasis (3). It can be seen between the ages of 29-90y. It is reported to be a rapidly growing mass with large diameters. The lesion can be cystic totally or can have cystic components like in our patient (4). It doesn't have characteristic radiologic images. Prognosis is related with many factors especially tumor size and stage. In treatment modified radical mastectomy and adjuvant chemo and/or radiotherapy with hormonotherapy in selected patients is the recommended modality. According to some reports, axillary dissection is not recommended because $70 \%$ of the patients do not have axillary involvement. Since it is a rapidly growing tumor and locoregional disease is frequent, breast conserving surgery is rarely possible $(3,5)$.
In conclusion, primary breast squamous cell carcinoma is a rare and aggressive disease with significantly worse prognosis. Clinicians should be aware of the early locoregional relaps and multiple distant metastases when counseling these patients. In differential diagnosis of the breast masses, especially in lesions with having cystic component and appearing to be benign, it should be taken into consideration.

\section{Conflict of interest}

No conflict of interest was declared by the authors.

\section{REFERENCES}

1. Weigel RJ, Ikeda DM, Nowels KW. Primary squamous cell carcinoma of the breast. South Med J. 1996; 89: 511-5.

2. Macia $M$, Ces JA, Becerra $E$, Novo A. Pure squamous carcinoma of the breast. Report of a case diagnosed by aspiration cytology Acta Cytol. 1989; 33: 201-4.

3. Hennessy BT, Krishnamurthy S, Giordano S, Buchholz TA, Kau SW Duan Z, Valero V, Hortobagyi GN. Squamous cell carcinoma of the breast. J Clin Oncol. 2005; 23: 7827-35.

4. Shigekawa $T$, Tsuda $H$, Sato $K$, Ueda $S$, Asakawa $H$, Shigenaga $R$, Hiraide $\mathrm{H}$, Mochizuki $\mathrm{H}$. Squamous cell carcinoma of the breast in the form of an intracystic tumor. Breast Cancer. 2007;14:109-12.

5. Cardoso F, Leal C, Meira A, Azevedo R, Mauricio MJ, Leal da Silva JM, Lopes C, Pinto Ferreira E. Squamous cell carcinoma of the breast. Breast. 2000; 9: 315-9. 